\title{
MUSLIM FUNDAMENTALISM: THE CASE OF SAYYID QUTB
}

\author{
Yasien Mohamed \\ Arabic Language and Islamic Philosophy \\ Department of Foreign Languages \\ University of the Western Cape
}

\begin{abstract}
This paper deals with the concept of Muslim Fundamentalism and places Sayyid Qutb within this broad context. The paper discusses two key concepts of Qutb's fundamentalism, namely jihad (struggle) and jahilliyyah (ignorance). Qutb introduced a new understanding of ignorance, which originally referred to non-Muslims, but which for Qutb can also refer to those Muslims in government who do not live by the laws of God (Shari'ah). The paper also seeks to examine his last work, Milestones, which led to his death-sentence in 1960 by the Gamal abd al-Nasr regime of Egypt. There is no doubt that the impact of Qutb's thought is still felt today, and some would even argue that he is the main inspiration for contemporary Islamic terrorism.
\end{abstract}

Key words: Qutb, Islam, Fundamentalism, jihad, jahiliyyah, shar'iah, Milestones, Nasr, Egypt, Ikhwan

\section{Introduction}

The term 'fundamentalism' first emerged within the American Protestant tradition in the $19^{\text {th }}$ century, and signifies a belief in the literal interpretation of the Bible. It is inappropriate with respect to Islam because all Muslims, whether conservative, militant or liberal, believe in the Qur'an as the literal word of God. The media sense of the word is derogatory; so we will use it in the academic sense to refer to Muslims who want to revive the fundamentals of Islam. Muslim fundamentalism is not monolithic; there are variants of it. In general it supports a literalist reading of the Qur'an, and is averse to the legal (madhhab), theological (kalam) philosophical and Sufi schools. Not all Muslim fundamentalists are militant. The Wahhabis in Saudi Arabia, for example, support jihad in theory, but not in practice (until Osama bin Laden came onto the scene). Other terms that are used for Muslim fundamentalism are Islamism, revivalism, resurgence and political Islam. The least derogatory term would be the Arabic word 'Salafiyyah' (return to ancestors), which implies a return to the practice of Prophet Muhammad and his companions. The puritanical Wahhabi movement is a branch of the Salafiyyah school. Modern reformers such as Muhammad Abdu, Rashid Rida and Hasan al-Banna are rooted in the Salafiyyah orientation. Ironically, the Muslim fundamentalists are calling for a return to the past, yet they are a product of modernity, and wish to embrace the future (On Muslim fundamentalism, see Antoun: 1989:236; Shepard, 1987:356-360; Rahman, 1981:64; Burrel, 1989:9-10; Mohamed, 1993:12-23; Mohamed, 1996:3-26; Mohamed, 1996:18-31).

Sayyid Qutb, the focus of this chapter, and one of the fathers of modern Muslim fundamentalist thought, located physical jihad at the centre of his vision of the twentieth century political Islam. Whereas political scholars tended to conceptualize his physical jihad as a 
war-like enterprise, Qutb reveals a different logic at work in the propagation of jihad as a primary means of political transformation. Sayyid Qutb was the ideologue of the Egyptian Muslim Brotherhood in the 1950s and 1960s, and became the most influential theorist of the Islamic revolution in Egypt and beyond. Through his writings, particularly Milestones (ma'alim fi tariq), he reinterpreted traditional Islamic concepts to justify a violent takeover of the state. His Milestones was used by the nationalist Egyptian government to incriminate him, and in 1996 he was hanged. His death elevated his status to shahid or martyr in the eyes of many Muslims and Milestones became a bestseller and widely distributed across the Arab speaking world. In its English translation it had a great impact on the thought of Muslim minorities in South Africa, Britain and America.

A study of Sayyid Qutb is relevant to South Africa because of the impact he had on the Islamic identity of the Muslim youth in South Africa, and the way in which he shaped their perspective to the struggle against Apartheid. He influenced the thought of Imam Abdullah Haron and the Muslim Youth Movement of South Africa (Rice, 1987:438-471), but the immediate effects of Qutb was felt in his own country, and so the focus of this study will be on the impact of his Qutb's thought in the context of Egypt.

Qutb saw Islam as a political movement, and while he opposed the secular nationalism that had dominated the 1960s, he also rejected the traditional Sunni or Shi'ate view that relegated political jihad to a secondary concern. He broke away from the established order, and attracted a new generation of Muslim youth, but alienated the middle class and the ulema. The 1960s was a period of nationalist ideology that gripped the Muslim countries, and was shaped by home-grown elites who had fought to break the stranglehold of European colonization and who led their countries to independence in the aftermath of World War Two. The nationalist sentiments among Egyptians and Iranians had fragmented the historic land of Islam into nation states that pursued the agenda of Arab nationalism or Iranian nationalism. The nationalists took control of the modern media and put it in the service of their own secular ideals; consequently excluding the ulema who were accustomed to the traditional religious forms of expression. Qutb rejected the nationalist goals and reactivated Islam as the political standard for Muslim behaviour.

Since the events of 9/11, Western media, which largely influences Western culture, has focused on Islamic fanaticism and Muslim political activism, and Western scholars, including Karen Armstrong, have identified Sayyid Qutb as the main ideologue of fundamentalism in contemporary Islam. However, Middle Eastern scholars regard Qutb as one of the leading scholars in Islamic history, and indeed, his thought constituted the premises of many radical Muslim groups, especially in Egypt (Abu Rabi', 1996:94). It is true that there is an extensive amount of information on Muslim fundamentalism, but yet, Qutb occupies a central place in the scholarly output on the phenomenon of political Islam. His thought, Islamic activism, and finally his execution by the Nasser regime, exemplify the life of a Muslim fundamentalist, which many Muslims aspire to imitate. We will discuss two main concepts that shaped his fundamentalist Isamic thought, namely, his view of jahilliyyah (ignorance) and his view of jihad (struggle).

\section{Qutb's View of Jahilliyyah}

Sayyid Qutb was born in Upper Egypt in 1906, and later became a devout student of the literary giant Mahmud al-'Aqqad, who influenced Qutb profoundly, and encouraged him to emerse himself in Western literature. Qutb was confused by this mass of secular literature, but later, when he undertook a serious study of the Qur'an, albeit from a literary perspective, he rediscovered his true identity, and returned to his religious roots. This was a 
turning point in his life. He did, however, not regret his study of the Western human sciences, which enabled him to develop a critical appraisal of the intellectual jahiliyyah (ignorance or babarism) of the time. His taswir al-fanni fi al-Qur'an was originally undertaken with literary intent to examine the Qur'an, but it had a profound impact on his understanding of the Qur'an as a revealed book.

In 1984 his al-Adalah al-Ijtima'iyyah fi'l Islam (Social Justice in Islam) was published. This was his first major Islamic book, which he started writing before his study in America. No clear view of jahiliyyah was expressed in this book, but in the same year, his criticism of jahiliyyah emerged in his edited journal, al-fikr al-jadid. His Social Justice in Islam represents his shift from pure literary concerns to more social issues in Egypt. He dissects socio-economic and political problems in the light of what he perceives as genuine Islam. He was at this stage more committed to the plight of the peasants and workers, and represented a phase of moderate Muslim fundamentalism. Abu Rabi' describes it as his "newly discovered Muslim social commitments to the plight of the poor in society" (Abu Rabi, 1996:109). To be sure, Qutb identified himself with the oppressed peasantry probably because he himself came from a peasant background. His main contention is that social justice cannot occur if the material conditions of the people are not improved. Food and shelter are a prerogative of the poor (Abu Rabi', 1996:120). Qutb comes across here as a social critic of Egyptain society, and with a radical Islamic agenda, he identifies the enemies who are the hurdles of social justice. Once he identified the enemies, he pondered over the means to remove them. Integral to the indentification of the enemy, is the concept of jahiliyyah.

To understand his concept of jahiliyyah we need to turn to his last, but most influential work, Ma'alim fi Tariq (Milestones). Already in his Qur'anic commentary, preceding Milestones, he wrote about the enemy, but did not identify them so explicitly, and focussed on those enemies who are opposed to Islamic belief ('aqidah) (Abu Rabi', 1996:189). It is only in Milestones that he clearly identified the enemy as one who belongs to the system of jahiliyyah, and he called for the removal of this jahiliyyah. The means for this removal is jihad, which is really a defense of the Islamic belief. At this stage, Qutb already joined the Ikhwan, and when al-Aqqad saw Qutb moving in the Islamic direction, he stopped his moral support, and Qutb eventually parted company with him (Ushama, 2005:233-234).

It is wrong to explain Qutb's jahiliyyah purely in political terms. Indeed, he did condemn Western systems of governments, but before he directed his militant jihad to the regime change of jahiliyyah systems, he already had a critical view of the Western literary jahiliyyah, even before he went to America. However, he became more alive to the moral jahiliyyah of Western society when he stayed in America. Thus, his negative attitude to jahiliyyah in the West was not only political, but also moral and intellectual. He was disgusted not only by Western immorality while in America, but also by the empty theories and philosophies which he read before his visit to America. He was even more disgusted by the Arab Muslims in America who became so engulfed by American culture, and who compromised their Islamic principles. He took a firm stand not to follow this path. Thus, his critical attitude towards Muslims at a social level was transferred to Muslims who made such compromises at a political level. Thus, Qutb's critique of Western immorality, secular modernity, and Muslim hypocricy, have all combined to shape his anger at the West and the Muslim regimes that collaborated with them.

Jahiliyyah was for him a comprehensive concept, social, political, moral and intellectual. The jihad against jahiliyyah also takes on all of these forms, but towards the end of his life, when he wrote Milestones, he was convinced that the social, intellectual and 
moral expressions of jahiliyyah could only be transformed by changing the political jahiliyyah of his time, and this meant regime change. By changing the superstructure of society; by changing the jahiliyyah political systems, starting with Egypt, the whole society will change to an Islamic society. Like al-Banna, Qutb also held the view that man-made ideologies will corrupt the spiritual life of humanity. These jahiliyyah ideologies, especially, Capitalism and Communism, had to be replaced by a political system based on the rule of Shari'ah.

Qutb divided Egyptian society into two: the Capitalists who lived in luxury, and exploited the labour of the majority of the people, and the poor workers who have been exploited. Thus he called upon the liberation of the poor and the labourers from exploitation from colonialism and feudalism. Capitalism is tied up with European nationalism and exploitation and presents a challenge to Islam. Socialism is also not the alternative, although it provides minimum standards of living, empolyment, housing, social justice. Socialism conflicts with the concept of tawhid. Marxism neglects human spiritual needs and explains history purely in material terms: " Marxism is completely ignorant of the human soul, its nature and history... It ascribes all incentives to the feeding of material human wants and to struggle for material gain. It describes all historical events as due soley to change in the means of production" (Ushama, 2005:249). Islam must inevitably clash with Marxism; Islam establishes belief in God, but Marxism denies God; Islam harmonizes between the material and spiritual needs of man, but Marxism only concerns itself with man's material needs (Ushama, 2005:249).

For Qutb, the Islamic society asserts tawhid, and opposes all false gods. It grants the individual free will and asserts only the sovereignity of God. The Jahiliyyah society is a society of shirk (polytheism) and rejects God as the sovereign, and submits to false gods, the worship of man, tyrants, ideologies. Communism, for example, denies God, surrenders to the will of the party, and cares only for man's material needs. This is an example of a jahiliyyah government that derives its laws from a human source, not from a revealed law or Shari'ah. Muslim countries that are ruled by man-made laws are also jahiliyyah; they are the product of the soul of desires (Qutb, 1989:241,247).

There are two other points in his personal life that needs to be mentioned so that we can have a more comprehensive view of the factors that shaped his thought, especially his negative view of the West and of the contemporary Egyptian regime. The one point is the jubilant response of Americans when they heard of the death of Hasan al-Banna. While he was in hospital in America, he could not understand the reason for the American jubilance, and then he discovered that they were happy because the main Muslim terrorist had died. Qutb states: "Hasan al-Banna was assassinated in 1949, my attention turned with severity to what American and European newspapers had observed and commented out of malicious joy and candid jubilance shown by them in dissolving the society, torturing its members and the killing of its General Guide" (cited in Ushama, 2005:235). Due to al-'Aqqad's influence, Qutb was not really interested in the Muslim Brotherhood, and he had not even met Hasan al-Banna, but the American elation about al-Banna's death stirred his interest toward the Brotherhood and their objectives.

Another factor in his life that shaped his view of jahiliyyah and jihad was his imprisonment and severe torture by the regime of Gamal Abdal Nasr. The Ikhwan at first supported Nasr when he assumed power in 1952, and saw in Nasr's Egypt an opportunity to build a society without divisions, guaranteed by the implementation of an Islamic order. But Nasr's nationalist agenda conflicted with the Islamic agenda of the Ikhwan, and led to bloodshed. After the attempt on Nasr's life, which was blamed on the Ikhwan, the 
organization was dissolved, and their members were jailed, exiled or hanged. Those who were in exile spread the message of the Ikhwan to other countries; but followers of Qutb have reassessed his thought, and adapted it for their own conditions, some have taken on a radical stance and others a more moderate position (Kepel, 2006:30). After his severe torture in prison, Qutb wrote Milestones, his most influential work where he explained the concept of jahiliyyah and jihad. This is the work that inspired Muslim militant movements throughout the world, and today, some Western scholars are saying that Qutb is the main source of current Islamic terrorism. It should be made clear at this point, although Milestones called for a militant jihad, it was not directed at innocent civilians but at corrupt systems of government.

For Qutb, the post-independence history of the Muslim states had no inherent value, and called it Jahiliyyah (ignorance or babarism), which traditionally refers to the pre-Islamic Arabs who worshipped stone idols, but for Qutb, it is also applicable to his contemporaries who worshipped the metaphorical idols of nationalism and socialism. His Fi Zilal alQur'an (In the Shade of the Qur'an) and his Milestones, written in the 1960s, called for a new Qur'anic generation to replace the contemporary paganism of nationalism and socialism just as the Prophet and his companions had built a Quranic generation on the ruins of Arab paganism (Kepel, 2006:26). Before his release from prison Milestones was published in 1964. It consisted of some of the letters Qutb had sent from prison and key sections from In the Shade of the Qur'an, and represented a concise, but powerful, summary of his ideas (Qutb, 2000:9).

The antithesis of jahiliyyah was Islam, which he defined in accordance with two concepts he borrowed from Mawdudi, 'Ubudiyyah (servitude to God alone) and Hakimiyyah (divine sovereign). Only God is sovereign, and only He is worthy of worship. The idea of divine rule is based on an interpretation of the Qur'an, traditionally translated as divine judgement, but for Qutb it meant the government of God. Thus, Jahiliyyah, refers to all those regimes that do not conform to divine law; in Qutb's time it refers to the Capitalist and Communist regimes.

\section{Qutb's View of Jihad}

One cannot separate Qutb's view of jihad from his view of jahiliyyah; they go hand in hand, and so when we discuss his view of jihad, it will invariably refer to those jahiliyyah regimes that are obstacles to a just and free society based on the principles of tawhid. And since they are obstacles, they have to be removed. The method of their removal is through jihad.

Qutb died before he could elaborate on these concepts, but there have been followers who have interpreted him in a more militant way to refer to whole societies living in a state of metaphorical paganism. If Qutb's jihad is directed at regime change and not whole societies, then the Western stigma attached to Qutb as the father of modern Islamic terrorism is unfounded. He is, however, the father of present-day Islamic resistance throughout the Middle-East.

As mentioned, there were many factors, including Nasr's repression that provided the context for the crafting of Qutb's Jahiliyyah. This modern babarism must be removed as the Prophet struck the original jahiliyyah, and be replaced by the Islamic state. This is a radical departure from the traditional view, and even the view of the original members of the Ikhwan. What it meant is that Egyptian society as a whole is not Muslim, and that certain members who are impure are no longer Muslim by virtue of their impiety. This places them in the category of takfir, which means that they have to be excomunicated from 
the society.This appears to be a neo-kharijite view, but the majority of Ulema over the centuries were cautious not to apply this as it would imply dissension and discord within the community.

According to Kepel, Qutb died before he could explain what exactly he meant by jahiliyyah. This is an interesting point as it leaves Qutb's view of jahiliyyah open to interpretation. Kepel identified three readings of jahiliyyah that emerged among the followers: they pronounced takfir on the whole society except for their members; they confined it to the rulers of the state who did not rule according to the divine text; lastly, the rupture with jahiliyyah society meant a spiritual not material rupture. The third view was held by those Ikhwan who lived outside Egypt. They saw Husayn al-Hudhaibi, sucessor to al-Banna, as their leader, and focussed on preaching, not condemning. The younger brothers tended to take a hard-line, but the maturer members were against the harsh radicalism and preferred political compromise (Kepel, 2006:31). Thus, the moderate followers of Qutb, or the Ikhwan, will have a softer approach to social change, and give more attention to the propagation of the message than to physical jihad. The more militant members will have a different reading, and apply jahiliyyah and takfir to all those Muslims who do not conform to their view, and not only to foreign and unIslamic political systems. The different manifestations of Qutb's message are more visible outside Egypt, including South Africa, but discussion on this matter will require a separate treatment.

By 1967, the Arab nation states were defeated by Israel, and Qutb's ideas were given new life, and further inspired by the non-Arab ideologues such as Mawdudi in India and Shari'ati in Iran.

As noted above, crucial to the understanding of jihad is Qutb's innovative concept of jahiliyyah. In addition, his later view that jihad is not merely defensive, but also aggressive, is especially noteworthy for an understanding of his concept of jihad. This more aggressive view of jihad is not present in his Social Justice in Islam, but in his Milestones (Qutb, 1980:62-91).

Qutb's basic point of departure in Milestones is that all systems, Capitalism or Communism have failed. He holds that Islam is in the hearts of believers and that it has been abandoned by the rulers and elites. We have recreated the pre-islamic jahiliyyah; so we should fight this new ignorance which has poisoned the governments of Muslim countries ( Cook, 2005:103). Islam and jahiliyyah cannot coexist. For Islam to surpass jahiliyyah we have to purify it of the jahiliyyah customs and traditions that have crept into Islam, and that have made it impossible for people to see that Islam is the way to cure humanity of its ills. We have to return to the unique Qur'anic generation; the first generation that knew only the Qur'an. This new generation should be the concrete manifestation of Islamic belief ('aqidah), embedded within the human soul, and it is this generation that is able to challenge the human elements of jahiliyyah (Qutb, 1980:45).

The traditional view of jihad such as the expansion of territory or defending its borders did not seem to concern him much; nor the view that the greater jihad (struggle against the lower self) is superior to the lesser, armed struggle jihad (Schleifer, 1983; Schleifer, 1984). For him, jihad is against all systems of anti-God or anti-shari'ah governments, whether they are in Muslim countries or non-Muslim countries. The armed-struggle jihad cannot be separated from the inner jihad; the inner jihad, although important for piety, cannot take the place of armed struggle jihad, which is intergral to it (Qutb, 1980:62-91; Cook, 2005:106).

Qutb was not an apologist for jihad, and as mentioned, proclaimed that Islam was not merely defensive, but also offensive. He criticised very strongly those Muslim scholars who are apologetic about jihad, and considered them to have a mental and spritual defeatist 
attitude (Abu Rabi', 1996:194). However, although offensive, it is not coercive in its goals; but a means by which God's message can be heard and by which peace can be established. For this to happen, the superstructures that impede the freedom of this message, have to be removed. Jihad and proclamation are linked together:

Jihad is necessary for proclamation, since its goals are to announce the liberation of man in a manner that will confront the present reality with equivelent means in every aspect, and it does not suffice with hypothetical and theoretical proclamations, whether the Islamic lands are safe or threatened by neighbours (Qutb, 1980:62-91).

Peace is defined as when the religion belongs to God alone, and no other Lords are competing with Allah. Jihad is not modern war, it is within the very temperament of Islam, which has given it a true role (Qutb, 1980:62-91).

It is this jahiliyyah that impedes the Islamic movement from establishing the Law of God. It should therefore be removed, even by means of violent jihad. Qutb states:

It is the right of Islam to move first, for Islam is not the belief of a single group, nor the system of the state, but a divine way and a global system. Thus it has the right to move [ahead] and to destroy impediments, whether systems or statutes, that fetter human freedom of choice. It does not attack individuals, compelling them to embrace its creed, but attacks systems and statutes to liberate individuals from the corrupt influences that corrode innate human nature and restricts human freedom of choice (Qutb, 1980:89).

By its very nature, Islam is global and aggressive; either the world hears Islam, and has the freedom to accept or reject it, or it does not. Anti-God constitutions will not allow humanity that choice, only an Islamic state with divine law will. A case is made for the aggressive nature of jihad, but it is directed at freedom of choice for humanity. After all, there is no complusion in religion.

For Qutb there are only two systems, Nizam al-Jahili (the system of ignorance) or Nizam al-Islam (the system of Islam). These two systems cannot coexist, and so where a system of ignorance exists, it should be removed, and we should against it as we are in the Home of hostility (Darul Harb).

This Islamic homeland is a refuge for anyone who accepts the Islamic Shari'ah to be the Law of the State, as is the case with the dhimmis. Any place where the Islamic Shar'iah is not enforced, and where Islam is not dominant, becomes the Home of Hostility (dar alharb) for Islam, the Muslim and the dhimmi. A Muslim will remain prepared to fight against it (Qutb, 1989:223).

Qutb states in uncompromising terms that Islam represents the command of God which cannot coexist with the system of jahiliyyah, which represents the command of man. A Muslim's duty is therefore to remove jahiliyyah from the leadership of man. 'The tree of Islam has been sown and nurtured by the wisdom of God, while the tree of jahiliyyah is the product of the soul of human desires' (Qutb, 1989, 241; 247). The struggle against jahiliyyah is imposed on Islam, and Islam has the right to remove all political obstacles that prevent it from addressing human reason and intuition.

Islam conforms to human nature; and it is able to challenge jahiliyyah without undergoing transformation itself. Even Muslims who practice the way of Jahiliyyah cannot be regarded as Muslims; and should be returned to Islam because they impede the Islamic movement from establishing the Law of God in the form of an Islamic State (Mohamed, 1996:19).

There is a conflict between truth and falsehood, and Islam and jahiliyyah, they cannot live together. The need to remove the system of jahiliyyah and establish God's rule makes jihad imperative. Good and evil are dialectical elements in society; through Islamic 
struggle, evil will be conquered, and good, which is harmonious with fitrah or innate human nature, will prevail.

In summary, Qutb had an absolute view of the problems facing the Muslim world, arguing that these problems stemmed from the fact that Muslim societies were no longer ruled by Muslim norms and laws (the shari'ah) and had become apostate by their imitation of foreign laws. Since (true) Muslims were visibly in the minority, they must concentrate upon (re)making society Muslim, and return to the Qur'anic generation. His Milestones was the basis for the charges against him; it was his final testament for which he was prepared to die. It captures his militancy towards Western systems of government, especially in Muslim countries. Peace and free choice are only possible with divine law. Every other law, every other system, is jahiliyyah, and must be defeated. The word of God should prevail and be dominant. This was for Qutb the very temperament of Islam, which became a mark of his own personality and temperament.

\section{Conclusion}

Qutb espoused an innovative dialectic conception of jihad that is directed at unjust political authority, which he refers to as jahiliyyah (Qutb). He was critical of the traditional ulema who depoliticised Islam, and who collaborated with the despots of the day. He held the view that the new government should rule by the principle of tawhid (Shari'ati) or Shari'ah (Qutb), but did not envisage an Islamic state ruled by the ulema.

In South Africa, his Milestones, which was translated into English, had an impact on Muslims in South Africa, during the Apartheid era. It gave them an Islamic perspective to the struggle in South Africa, and provided an alternative to secular ideologies such as Marxism and Black Consciousness. His writings are less popular today in a new democratic South Africa, but they still provide a basis for critique of the state when it is too liberal with respect to moral values and too slow in overcoming the increasing unemployment, poverty and crime in the country. 


\section{BIBLIOGRAPHY}

Abu-Rabi', Ibrahim M 1996. Intellectual Origins of Islamic Resurgence in the Modern Arab World. New York: State University of New York Press.

Antoun, RT 1989. Muslim Preacher in the Modern World. Princeton: Princeton University Press.

Burrel, RM 1989. "Introduction: Islamic Fundamentalism in the Middle East-Survey of its origins and diversity" in Islamic Fundamentalism (ed. RM Burrel), London: Royal Asiatic Society.

Cook, David 1982. Understanding Jihad. Berkeley: University of Califonia Press, 2005. Enayat, H, Modern Islamic Political Thought. London: The Macmillan Press Ltd, London.

Haron, M 1986. "Imam Abdullah Haron: Life, Ideas and Impact". MA thesis, University of Cape Town.

Hourani, Albert 1962. Arabic Thought in the Liberal Age. London: Oxford University Press.

Loboda, Luke 2004. The Thought of Sayyid Qutb, Ashbrook Statesmanship Thesis Recipient of the 2004 Charles E Paton Award, Ohio.

Mortimer, Edward 1982. Faith and Power: The Politics of Islam. London: Faber and Faber.

Mohamed, Yasien 1996. "Jihad and Fitrah in the Thought of Qutb and Shari' ati". Journal for Islamic Studies, 3-26, Mellville.

Mohamed, Yasien 1993. "Islamization: A Revivalist Response to Modernity". Muslim Educational Quarterly. 10(2):12-23, Winter.

Mohamed, Yasien 1996. "The Educational Life and Thought of Muhammad 'Abdu”. Muslim Education Quarterly, 13(4) 18-31.

Moussalli, Ahmad S 1977. Radical Islamic Fundamentalism: The Ideological and Political Discourse of Sayyid Qutb. Beirut: American University of Beirut Press.

Mussalam, Adnan 1993. "Sayyid Qutb and Social Justice", Journal of Islamic Studies 4 (1) 52-70.

Qutb, Sayyid, trans. JB Hardy and H Algar, (reprint) 2000. Social Justice in Islam. New York: Islamic Publications International, Kualu Lumpur: Islamic Book Trust.

Qutb, Sayyid 1989. Ma alim fi Tariq, Beirut: Dar al-Shuruq, 980/ Trans. Qutb, Milestones, (tr. MM. Siddique), IFSO.

Qutb, Sayyid 1979. Fi-Zilal al Qur'an, Beirut: Darul-Shuruq.

Qutb, Sayyid 1990. Milestones. Indianapolis: American Trust publication.

Qutb, Sayyid, trans. JB Hardy and H Algar, 2000. Social Justice in Islam. New York: Islamic Publications International.

Qutb, Sayyid 2000. “ The America I have seen”, New York.

Rice, DC 1987. "Islamic Fundamentalism as a major Religiopolitical Movement, and its impact on South Africa", MA thesis, UCT.

Schleifer, A1982. "Jihad and Traditional Islamic Consciousness", Islamic Quarterly 27.

Schleifer, A 1983. "Understanding Jihad: Definition and Methodology" Islamic Quarterly, 28, 117-131.

Schleifer, A 1984. "Jihad: Modern Apologists, Modern Apologetics, Islamic Quarterly, 28, $25-46$.

Shepard, William 1987. "Fundamentalism: Christian and Islamic" in Religion.

Ushama, Thameem 2005. "Sayyid Qutb: Life, Mission and Political Thought" in Contemporary Islamic Political Thought: A Study of Eleven Islamic Thinkers. Kuala Lumpur: International Islamic University Malaysia. 